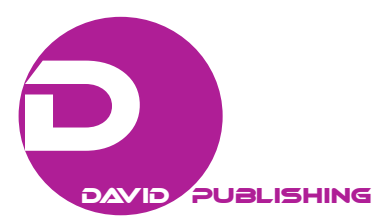

\title{
The Silk Road Imaginary in the Central Asia as an Emerging Geopolitical Discourse
}

\author{
Cavit Emre Aytekin, Elnur Hasan Mikail \\ Kafkas University, Kars, Turkey
}

\begin{abstract}
This paper examines the use of geopolitical imaginaries, historical narratives, and discourses in Central Asian politics which have always been used in geopolitical agendas of both regional and external actors. The main focus in this study is the Silk Road myth as a prominent case of those geopolitical imaginaries. The Silk Road discourse presents a definite example of mythmaking and geopolitical discourse in the Central Asia used by both regional actors such as China, Russia and external actors such as the United States. The main argument of this study is that each of those actors is referring the historical myth of Silk Road as a useful tool for pursuing their geopolitical vision and interests. So questioning this situation is important in the eyes of critical geopolitics because the same historical fact is constructed with different meanings and visions by different actors in accordance with their competing interests. In this study, the critical geopolitical theory and method are used to describe the emerging geopolitical discourse in the Central Asia such as: rising powers narrative, peaceful rise concept, and silk road imaginary.
\end{abstract}

Keywords: the Silk Road, geopolitical discourse, critical geopolitics

\section{Critical Geopolitics}

As international relations discipline is progressing through theoretical debates, the traditional concepts, thoughts, and ideas are being challenged by new approaches. The critical turn in international relations is a product of such a debate process and the critical theory, in general, it brought new conceptual isations of ontological and epistemological understandings. Those ontological and epistemological arguments brought by the critical theory are as a matter of course encountered in geopolitics. And as in the other realms of the international relations discipline, the study of geopolitics started to face the critique of positivism as the critical theory reached to the theoretical background of classical geopolitics with its contemporarysocial and political interpretations.

In geopolitics, positivism is incapable for explaining the relationship among places, spaces, and politics in international level (Dalby, 1991, p. 269). Especially, it's fundamentally a priori assumption of distinction between geography as a material external world out there, and the states as main political actors have an insufficient understanding of critical concepts such as practice, subject, object, and the role of discourse. So the

Cavit Emre Aytekin, res. asst., Department of Political Sciences and International Relations, Faculty of Economics and Administrative Sciences, Kafkas University, Kars, Turkey.

Elnur Hasan Mikail, ass. prof., Department of Political Sciences and International Relations, Faculty of Economics and Administrative Sciences, Kafkas University, Kars, Turkey.

Correspondence concerning this article should be addressed to Elnur Hasan Mikail, Department of Political Sciences and International Relations, Faculty of Economics and Administrative Sciences, Kafkas University, Kars, Turkey. 
so called importance of some places and the concretizing of international politics through drawing attention to borders and maps neglect their historical constructed nature. The methodological and theoretical considerations have frequently been given short shrift in international relations debates. The assumption built into the enterprise is of the difference between political community which exists within states and the absence of such a community in the international arena. Critical theory opens up the investigation to explore the possibilities for change and the structural linkages between the materials which are focused on its larger context.

As stated above parallel to the debates in international relations theory, the political geography has been entered into meta-theoretical discussions. And discursive practices of international relations became a major subject of political geography. Geography's traditional role is changed and along with the critical theory approach, traditional concepts such as power, interest, war, peace, violence, war, and the international system came into question (Painter, 2008, p. 61). Thus, critical geopolitics became trending approach in analyzing geopolitical models, imaginaries, and discourses such as the Silk Road narrative.

The critical geopolitics focuses on the writing of worlds or the constructions of geographies according to Gearoid Tuathail, a major critical geopolitician (Tuathail, 1992, p. 191). This is the effect of post structuralist approach in the political geography and in fact the methods and ideas of critical geopolitics mostly originated from the Foucault's ideas on the power knowledge connection and the constructive importance of discourse (Dodds, Kuus, \& Sharp, 2013, p. 8). So in the view of critical geopolitics, the political geography is discursive.

The essential stages of constructing a geopolitical discourse are naming of territories, appealing to history, historical narratives, and mythos and consequently constituting a geopolitical imaginery of places. Here, the construction process begins with the division of places into "our" area and "their" area; its political function is being to incorporate and regulate "us" or "the same" by distinguishing "us" from "them", the same from "the other” (Dalby, 1988).

Critical geopolitics explores geopolitical perceptions of the Silk Road narrative through considering its relationship with the discourses, practices, and identities of relevant political actors. Analyzing the Silk Road from critical geopolitics perspective will uncover a concrete example of constructing a geopolitical narrative and provide possibility to determine to what extent historical narratives can be exploited in a process of artificially charging a geographical space.

Critical geopolitics considers geopolitics as a discourse of worldview perceptions and political culture, as opposite to the classical understanding of objective knowledge (Tuathail, Routledge, \& Dalby, 2006, p. 11). Therefore, the Silk Road can be interpreted as a geopolitical imaginary of regional and external actors. Because along with Russia and the US, China has also entered the realm of Silk Road mythmaking since the early 1990s, and India's foreign policy narratives contain mythological features as well.

\section{The Usage of Silk Road Myth as a Geopolitical Construct}

There are different visions of the Silk Road showing competing imaginations and interests of different actors who use geopolitical discourses to pursue those interests (Fedorenko, 2013). International actors suppose the revival of the Silk Roads in post-Soviet era as a new geopolitical narrative and referred this discourse as a useful instrument to promote their own interests in Central Asia. By the use of this notion in foreign policy discourse, different actors charged its meaning with different specific characteristics (Fedorenko, 2013). In this part, an overview for the usages of Silk Road myth in different actors' geopolitical discourse is presented. In doing so, the main aim is to discover the instrumentalization of a geographical concept in accordance with the 
interests of great powers.

The Silk Road metaphor has been used in a variety of discourses of different actors such as Japan, China, Russia, India, and the US. For instance, Japan, emphasized the "Silk Road diplomacy" in 1990s and in 2002 had initiated the "Silk Road Energy Mission" for the purpose of engaging in the energy market, in addition to its "Central Asia plus Japan” initiative (Len, Tomohiko, \& Tetsuya, 2008, p. 7). South Korea also used the Silk Road myth as a historical and cultural argument which is used to strengthen economic relations with Central Asia (Evans, 2012, p. 74). India as another regional actor has number of times appealed the concept of Silk Road in its claims of cultural and identitical relations with the region.

China has the biggest share in using the Silk Road metaphor especially in recent years. Chinese direct investment in Central Asia has increased and as China is getting more involved in Central Asian politics, economics through direct investments in infrastructure of transport, communication, and energy market, its usage, and possessing of the Silk Road narrative become more appeared.

China has used the Silk Road metaphor since the early 1990s but Beijing made it an official policy only in September 2013 in convention of Chinese President Xi Jinping. China started to officially use the Silk Road metaphor through introducing its "Silk Road Economic Belt” project in 2013 (Laruelle, 2015, p. 362).

The Silk Road Economic Belt project corresponds a geographical axis in Central Asia from China towards European continent passing through Kazakhstan, Afghanistan and going west through Iran and Turkey to achieve the Mediterranean and Europe. Chinese president Xi Jinping officially introduced the project in 2013 and reported that China would contribute $\$ 40$ billion to set up the Silk Road Fund (WSJ, 2014). China referred ancient Chinese Silk Road to justify its interests in this project and denominated it as "Twenty-First Century Maritime Silk Road”, which associates China with the Southeast Asian nations, Africa, and Europe through the Indian Ocean (Len, 2015).

However, the Silk Road narrative of the US has different meanings from Chinese one. The US Silk Road strategy focuses on the revival of continental trade instead of the continental strategy based on infrastructure, railways, and maritime, seen in the meaning of the Silk Road in Chinese usage. As seen from Beijing's perspective, the Silk Road offers an opportunity for Chinese direct involvement in the Central Asia, and particularly contributed by Chinese writing of history and naming of places.

As stated, there are many Silk Road allegories of different actors in the Central Asia. Russia has another narrative of Silk Road. The use of the term in Russia was mostly likened with the metaphor of Eurasia (Laruelle, 2015, p. 361). Russia is another actor that operationalizes a geographical narrative to justify its involvement in the region. With its Eurasian terminology, Russia tries to project Central Asia as part of its influence sphere as Chine does in the Silk Road myth. Thus, Russia tries to disconnect Central Asia from other actors in the region through constructing the narrative of Eurasia.

The US is another representative of Silk Road narrative as a new geopolitical narrative after the collapse of Soviet Union. In the US, usage of Silk Road metaphor appears as a symbol of this geopolitical construct of Transport Corridor Europe-Caucasus-Asia (TRACECA) project which was introduced in 1993 (Laruelle, 2015, p. 364). It aimed to open up Central Asia and the South Caucasus through the creation of a vast transport and communications corridor. TRACECA still functions today as a European assistance project, but it did not impact the main regional trade trends. The United States had its own Silk Road strategy, too, in 1999 and again in 2006, the Congress tried-without success-to target US assistance to the former Eurasian space, specifically to Central Asia and the South Caucasus. 
This first US Silk Road conceptualization had geopolitical targets, the most prominent benefit of realizing such a geopolitical construct would be to decline the dependency of Post-Soviet Central Asian Republics on Russia.

Since 2011, the Silk Road metaphor has started to be used in US foreign policy to frame US strategy for Central Asia. The choice of the Silk Road narrative to give a certain depth to a relatively unstructured US policy toward Central Asia encapsulates the evolution of US strategic thinking since the collapse of the Soviet Union. The US Silk Road initiative has thus been developed around four goals (Biswal, 2015):

(1) Building a regional energy market.

(2) Facilitating trade and transport.

(3) Improving customs and border procedures.

(4) Linking businesses and people.

The US Silk Road strategy claims to offer a comprehensive vision towards Central Asia. Thus, this strategy conveys a background but a forward-looking idea, and interest in Asia-Pacific region. In this point, the competitiveness of different visions towards the same region and referring the same historical myth of Silk Road, the roles of Russia, China, Iran, and Europe have different articulations and linkages on Central Asia. Actually, the US project with the ones advanced by other external actors-obscures the strategic motivations behind the reorganization of economic dependencies in this part of the world.

The usage of Silk Road metaphor as a geopolitical imaginary is based on the idea that Central Asia constitutes a center for Asia-Europe commerce and can be constructed as a natural transit route for the 21st century goes against any statistical analysis or world trade. Today, three-quarters of the world's trade is carried out by sea, and continental trade is not likely to dethrone maritime trade just because, once upon a time, caravans traveled along these routes. Uzbekistan is and will remain one of only two countries in the world that are doubly landlocked. The US Silk Road approach emphasizes what appears to be the center of a map of Eurasia—not a network of contemporary trade flows.

As seen, the symbolic power of Silk Road analogy is useful. The disappearance of the Silk Roads was due to internal evolutions in the region as well as a changing global structure. It preceded imperialism and can by no means be explained solely by the "Great Game" between Russia and Great Britain in the 19th century. The old Silk Road discourse conveys transportation of goods and more importantly the ideas, cultures, and technology. It corresponds with an ideal of constructing great civilizations and fosters great innovations. Central Asia can have a similarly historic impact today. This begs the question as to how the United States, as the world's leading super power, can promote the idea that great innovations will come from building roads and rail ways. Such thinking represents a 19th century’s vision of "progress” and “development”.

The Silk Road metaphor has a confusing characteristic in the usages of different actors and this reality is less romantic, but it is more in accordance with what the region is today: a periphery of multiple other cultural and trade centers, and a "center" only in the geographical sense of the term.

\section{Conclusion}

As a conclusion, the Silk Road narrative is appealed by different actors as an instrument for their geopolitical vision towards Central Asia and their political involvement in the region. And this fact generates a clear case study for referring Critical Geopolitics to analyze a geopolitical discourse. Accordingly, different usages of the Silk Road myth for justifying different and competing strategies and ideologies are uncovered.

The US Silk Road tends, for instance, to conflate the Silk Road with the Heartland theory of Halford 
Mackinder. As a general argument of the critical geopolitics about the US geopolitical discourse throughout the cold war era, the notion of Heartland is used in US geopolitical theories. Similarly, today's Silk Road narrative appears to pursue this geopoliticized vision of a region critical to the destiny of the West and the leading great power status of the United States, with "connectivity” and trade routes replacing traditional power competition.

As a historical metaphor, the Silk Road provides a kind of meta-narrative for political involvement of regional and external actors such as China, Russia, Japan, India, and the US in the region similar to the Great Game discourse of 19th century. Thus, the metaphor underlines the rivalry of different actors in Central Asia on increasing their power and influence in the region.

The different usages of the Silk Road in the political discourse of Russia, China, and the US strengthen the assumptions of critical geopolitics.

\section{Bibliography}

Biswal, N. D. (2015). The New Silk Road Post-2014: Challenges and opportunities. Presentation at The Woodrow Wilson International Center for Scholars, Washington, D.C.

Dalby, S. (1988). Geopolitical discourse: The Soviet Union as other. Alternatives, 13, 415-442.

Dalby, S. (1991). Critical geopolitics: Discourse, difference, and dissent. Society and Space, 9, 261-283

Dodds, K., Kuus, M., \& Sharp, J. P. (2013). The Ashgate research companion to critical geopolitics. Farnham, Surrey, England: Ashgate.

Evans, A. (2012). South Korea's “New Silk Road” to Central Asia: Diplomacy and business in the context of energy security. In SAIS US Korea 2012 Yearbook. US-Korea Institute at SAIS: John Hopkins University.

Fedorenko, V. (2013). The New Silk Road initiatives in Central Asia. Rethink Institute: Washington, D.C.

Laruelle, M. (2015). The US Silk Road: Geopolitical imaginary or the repackaging of strategic interests? Eurasian Geography and Economics, 56(4), 360-375.

Len, C. (2015). China’s 21st century maritime Silk Road initiative, energy security and SLOC access. Maritime Affairs: Journal of the National Maritime Foundation of India.

Len, C., Tomohiko, U., \& Tetsuya, H. (2008). Japan's Silk Road diplomacy: Paving the road ahead. Washington, D.C.: Central Asia-Caucasus Institute.

Painter, J. (2008). The SAGE handbook of political geography. Los Angeles i.e. Thousand Oaks, CA: SAGE Publications.

Tuathail, G. (1992). Geopolitics and discourse practical geopolitical reasoning in American foreign policy. Political Geography, 11(2), 190-204.

Tuathail, G., Routledge, P., \& Dalby, S. (2006). The geopolitics reader. New York: Routledge.

WSJ. (2014). China to contribute $\$ 40$ billion to Silk Road Fund (2014, November 8). Wall Street Journal. Retrieved from http://www.wsj.com/articles/china-to-contribute-40-billion-to-silk-road-fund-1415454995 